\title{
Trendi razvoja e-uprave v Sloveniji
}

UDK: 35:659.2:004(497.4)

Anamarija Leben

Univerza v Ljubljani, Fakulteta za upravo

anamarija.leben@fu.uni-lj.si

Mateja Kunstelj

Univerza v Ljubljani, Fakulteta za upravo

mateja.kunstelj@fu.uni-lj.si

IZVLEČEK

Razvoj e-uprave, katere glavna cilja sta povečati učinkovitost in uspešnost poslovanja ter zagotoviti kakovostne in uporabnikom prijazne storitve, je v večini razvitejših držav, pa tudi v Sloveniji, v polnem teku. Prispevek skuša predstaviti trende v razvoju e-uprave v Sloveniji s poudarkom na ponudbi storitev, upoštevajoč rezultate raziskav, ki jih na Inštitutu za informatizacijo uprave na Fakulteti za upravo opravljamo že od leta 1999.

Ključne besede: e-poslovanje, e-uprava, informatizacija uprave, e-storitve.

\section{Uvod}

E-upravo $v$ njenem najširšem smislu lahko opredelimo kot "upravo, katere celotno delovanje temelji na uporabi elektronskih dokumentov, e-poslovanja in interneta $v$ njenem notranjem in zunanjem poslovanju, uvajanju novih sistemskih in organizacijskih rešitev ter novih modelov upravljanja" (cit. Vintar, 2004, str. 5), v ožjem smislu pa jo razumemo kot elektronsko poslovanje $v$ javni upravi na vseh ravneh (državni, regionalni in lokalni) ter $v$ vseh vejah oblasti (zakonodajni, izvršilni in sodni) (Kunstelj, 2004, str. 16). Uvajanje in razvoj e-uprave (v ožjem smislu) lahko torej analiziramo z več vidikov: z vidika zagotavljanja tehnološke infrastrukture (tako v upravi sami kot pri uporabnikih), zagotavljanja ustreznih pravnih podlag ter ponudbe e-storitev in povpraševanja po njih, pri čemer so uporabniki storitev uprave občani, podjetja in nevladne oziroma nepridobitne organizacije. Na področju zagotavljanja tehnološke in pravne infrastrukture je bilo $v$ Sloveniji narejenega veliko. Center vlade za informatiko je $v$ zadnjih petih letih zagotovil ključne tehnološke podlage za razvoj elektronskega poslovanja javnega sektorja z vzpostavitvijo računalniškega omrežja javne uprave (HKOM), sprejeti pa so bili tudi ustrezni zakoni in podzakonski akti, ki neposredno ali posredno urejajo to področje, kot so: Zakon o elektronskem 
Kunstelj, Leben

Trendi razvoja e-uprave v Sloveniji

poslovanju in elektronskem podpisu (Uradni list RS št. 57/2000, 30/2001, 25/2004, 73/2004), Zakon o varstvu osebnih podatkov (Uradni list RS št. št. 86/2004) ter Zakon o dostopu do informacij javnega značaja (Uradni list RS št. št. 24/2003). Prav tako se intenzivno razvija ponudba e-storitev, torej elektronsko poslovanje uprave z uporabniki, kar $\vee$ tem prispevku podrobneje predstavljamo $s$ pomočjo rezultatov raziskav, ki jih od leta 1999 opravljamo na Inštitutu za informatizacijo uprave na Fakulteti za upravo.

Preglednica 1: Raziskave Inštituta za informatizacijo uprave, opravljene na področju poslovanja s strankami v letih 1999-2003

\begin{tabular}{|c|c|c|c|c|c|}
\hline Raziskava & 1999 & 2000 & 2001 & 2002 & 2003 \\
\hline $\begin{array}{l}\text { Analiza spletnih strani (UE, občine, } \\
\text { ministrstva) }\end{array}$ & $x$ & $x$ & & & $x$ \\
\hline $\begin{array}{l}\text { Odzivnost (UE, občine, ministrstva, } \\
\text { državni zbor-DZ) }\end{array}$ & & $x$ & $x$ & $\mathrm{DZ}$ & $x$ \\
\hline $\begin{array}{l}\text { Analiza } 20 \text { osnovnih javnih storitev } \\
\text { dostopnih prek interneta }\end{array}$ & & & & $x$ & $x$ \\
\hline Portal e-Uprava & & & & $x$ & $x$ \\
\hline
\end{tabular}

Vse $\vee$ prispevku predstavljene raziskave temeljijo na merjenju in vrednotenju razvoja e-uprave. Avtorji (Lenk in Traunmüller, 2002; eEurope2005, 2002; OECD, 2003) ugotavljajo, da so postale meritve $v$ procesu razvoja in uvajanja e-uprave praktično nujne in celo njen sestavni del. Merjenje in vrednotenje razvoja e-uprave naj bi omogočalo:

- ugotavljanje napredka in trenutnega položaja v razvoju e-uprave;

- ugotavljanje stopnje uresničevanja ciljev, zastavljenih v različnih strategijah in akcijskih načrtih;

- ugotavljanje dejavnikov, ki vplivajo na razvoj in uvajanje e-uprave;

- ugotavljanje prednosti in slabosti obstoječega stanja;

- oblikovanje novih smernic, politik in ciljev;

- iskanje najboljših praks;

- in nenazadnje: primerjave med posameznimi organizacijami javne uprave, posameznimi državami in drugimi subjekti.

Vse našteto je bilo tudi vodilo pri zasnovi in izvedbi naših raziskav. V letu 1999 smo tako izvedli analizo spletnih strani upravnih enot, občin in ministrstev, ki predstavlja prvi poizkus merjenja razvitosti e-uprave (Vintar in ostali, 1999). Poleg odstotka navzočnosti organizacij na spletu smo $v$ tej raziskavi analizirali tudi nekatere vsebine spletnih strani (osnovni podatki o organizaciji, opisi nalog in pristojnosti, predstavitev razvojnih projektov, podatki o javnih razpisih in naročilih, opisi postopkov, obrazci za vloge ipd.), zanimalo pa nas je tudi, ali so spletne strani objavljene tudi v

\section{Uprava, letnik II, 2/2004}


katerem od tujih jezikov. Analizo smo ponovili v letu 2000, ko smo dodali še nekaj kazalnikov (Vintar in ostali, 2000a). V letu 2003 smo izvedli analizo spletišč z obsežnim naborom dodatnih kazalnikov za njihovo vsebino, analizirali pa smo tudi načine iskanja informacij in storitev na spletiščih in druge značilnosti spletišč (Vintar in ostali, 2003a; Kunstelj in Dečman, 2004).

$\checkmark$ letu 2000 smo prvič izvedli meritev odzivnosti upravnih organizacij tako, da smo na elektronske naslove upravnih enot, ministrstev, občin in poslancev državnega zbora poslali sporočilo namišljenega občana in merili čas, $v$ katerem smo prejeli odgovor, ter analizirali vsebine odgovorov. To meritev smo ponovili še v letih 2001 in 2003, v letu 2002 pa smo analizirali le odzivnost poslancev državnega zbora (Vintar in ostali, 2000a, 2003a, 2003b).

V letu 2002 smo obstoječim raziskavam dodali še analizo 20 osnovnih javnih storitev, dostopnih prek interneta (Vintar in ostali, 2003b; Kunstelj, 2004), ki smo jo opravili po metodologiji Evropske komisije (Cap Gemini Ernst \& Young, 2004), v okviru primerjalne analize razvitosti portalov življenjskih situacij pa smo izvedli tudi analizo slovenskega državnega portala e-Uprava ${ }^{\mathbf{1}}$ (Vintar in ostali, 2002b, 2003c). Obe raziskavi smo ponovili tudi v letu 2003.

Tako kot do sedaj bomo tudi v prihodnje (ravnokar tečejo raziskave za leto 2004) sproti, $v$ skladu z novostmi in trendi na področju razvoja e-uprave, posodabljali metodologijo merjenja in opravljali letne meritve.

\section{Analiza spletišč upravnih enot, občin in ministrstev}

\subsection{Metodologija analize spletišč upravnih organov}

Kot smo omenili že $v$ uvodu, smo $v$ letu 1999 začeli z majhnim naborom kazalnikov, s katerimi smo skušali oceniti vsebine spletnih strani upravnih organov. Nabor kazalnikov za analizo informacijskih vsebin spletišč se je skozi leta spreminjal (preglednica 2), kar je seveda treba upoštevati pri analizi razvoja vsebin spletišč. Poleg samih informacijskih vsebin spletišč smo v letu 2003 podrobneje analizirali tudi naslednje značilnosti spletišč: podatke o razvijalcih spletišča, ažurnosti informacij, stopnjo tehnološke razvitosti storitev, načine iskanja informacij in storitev, nekatere vsebine, ki se nanašajo na e-demokracijo (forumi, možnost posredovanja pripomb ipd.), posebne načine dostopa do spletišč in tehnologije za ljudi s posebnimi potrebami.

1 http://e-uprava.gov.si/e-uprava 
Kunstelj, Leben

Trendi razvoja e-uprave v Sloveniji

Preglednica 2: Nabor osnovnih kazalnikov za analizo vsebin spletišč

\begin{tabular}{|c|c|c|c|c|c|c|c|c|c|}
\hline \multirow{2}{*}{ kazalnik } & \multicolumn{3}{|c|}{ UE } & \multicolumn{3}{|c|}{ občine } & \multicolumn{3}{|c|}{ ministrstva } \\
\hline & 1999 & 2000 & 2003 & 1999 & 2000 & 2003 & 1999 & 2000 & 2003 \\
\hline $\begin{array}{l}\text { osnovni podatki (poštni } \\
\text { naslov, centralna tel. števil- } \\
\text { ka, elektronski naslov in } \\
\text { uradne ure) }\end{array}$ & $x$ & $x$ & $x$ & $x$ & $x$ & $x$ & $x$ & $x$ & $x$ \\
\hline vsaj en e-naslov & $x$ & $x$ & $x$ & $x$ & $x$ & $x$ & $x$ & $x$ & $x$ \\
\hline org. struktura & $x$ & $x$ & $x$ & $x$ & $x$ & $x$ & $x$ & $x$ & $x$ \\
\hline tekoče novice & & & $x$ & & $x$ & $x$ & & & $x$ \\
\hline arhiv dokumentov & & & $x$ & & & $x$ & & & $x$ \\
\hline naloge/pristojnosti & $x$ & $x$ & $x$ & $x$ & $x$ & $x$ & $x$ & $x$ & $x$ \\
\hline pravne podlage & & & $x$ & & & $x$ & & & $x$ \\
\hline cilji/vizija/strategije & & & $x$ & & & $x$ & & & $x$ \\
\hline projekti & & & $x$ & & $x$ & $x$ & $x$ & $x$ & $x$ \\
\hline poročila o delu & & $x$ & $x$ & & & $x$ & & & $x$ \\
\hline baze podatkov & & & $x$ & & & $x$ & & & $x$ \\
\hline seznam postopkov & & & $x$ & & & $x$ & & & $x$ \\
\hline opisi postopkov & $x$ & $x$ & $x$ & $x$ & $x$ & $x$ & $x$ & $x$ & $x$ \\
\hline obrazci za vloge & $x$ & $x$ & $x$ & $x$ & $x$ & $x$ & $x$ & $x$ & $x$ \\
\hline tuji jeziki & $x$ & $x$ & $x$ & $x$ & $x$ & $x$ & $x$ & $x$ & $x$ \\
\hline tehnologija za diskusije & & & $x$ & & & $x$ & & & $x$ \\
\hline javni razpisi & & & & & $x$ & $x$ & $x$ & $x$ & $x$ \\
\hline veljavni predpisi & & & & & $x$ & $x$ & & & $x$ \\
\hline osnutki predpisov & & & & & & $x$ & $x$ & $x$ & $x$ \\
\hline občinsko glasilo & / & l & l & & $x$ & $x$ & l & l & I \\
\hline člani občinskega sveta & l & l & l & & $x$ & $x$ & l & l & l \\
\hline seje občinskega sveta & l & l & l & & $x$ & $x$ & l & l & l \\
\hline proračun & l & l & l & & $x$ & $x$ & & & \\
\hline $\begin{array}{l}\text { tehnološka razvitost e- } \\
\text { storitev }\end{array}$ & $x$ & $x$ & $x$ & $x$ & $x$ & $x$ & $x$ & $x$ & $x$ \\
\hline povezave & & & $x$ & & & $x$ & & & $x$ \\
\hline $\begin{array}{l}\text { tehnologije za ljudi s } \\
\text { posebnimi potrebami }\end{array}$ & & & $x$ & & & $x$ & & & $x$ \\
\hline navigacija po spletišču & & & $x$ & & & $x$ & & & $x$ \\
\hline ažurnost & & & & & & $x$ & & & $x$ \\
\hline
\end{tabular}




\subsection{Rezultati}

Pregled navzočnosti posameznih upravnih organizacij na spletu (slika 1) kaže, da imajo vsa ministrstva (MIN) objavljene svoje spletne strani že od leta 1999. Več kot polovica upravnih enot (UE) ima objavljene spletne strani že od leta 2000, v letu 2003 pa je portal upravnih enot nadomestil spletne predstavitve posameznih upravnih enot ${ }^{2}$, tako da so na spletu predstavljene vse UE. Odstotek občin, ki so predstavljene na spletu, se povečuje; največja rast je vidna do leta 2001, v nadaljnjih letih pa se upočasnjuje. Razlog je verjetno $v$ tem, da morajo občine same skrbeti za postavitev svojih spletnih strani, medtem ko za enotno predstavitev UE od leta 2003 skrbi Direktorat za javno upravo na Ministrstvu za notranje zadeve, od konca leta 2004 pa Ministrstvo za upravo.

\section{Slika 1: Navzočnost upravnih organizacij na spletu}

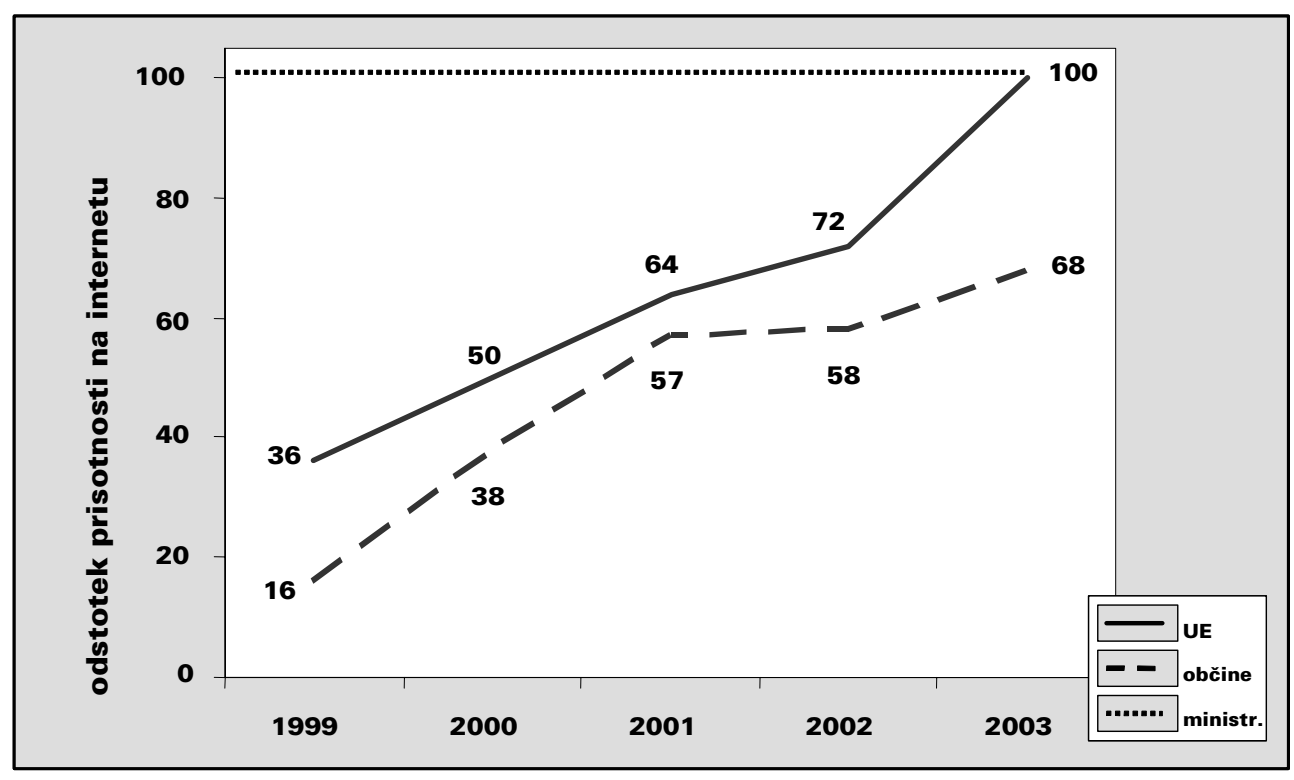

Analiza vsebin spletišč UE (slika 2) kaže porast pogostosti vseh predstavljenih vsebin razen poročil o delu in predstavitve $v$ tujih jezikih, česar $v$ letu 2003 nismo zasledili, saj portal UE teh vsebin ne vključuje. Prav zaradi portala UE pa je kar nekaj analiziranih vsebin $v$ letu 2003 predstavljenih pri vseh UE. Prednost portala pred spletnimi stranmi posameznih UE je $v$ tem, da so sedaj informacije in storitve zbrane na enem mestu in na enoten način, s čimer je tudi njihovo vzdrževanje lažje in učinkovitejše. Pri tem se informacije in storitve nanašajo predvsem na upravne postopke, katerih izvajanje je ključna naloga UE. Posebej velja pohvaliti enoten

2 http://upravneenote.gov.si/upravneenote 
Kunstelj, Leben

Trendi razvoja e-uprave v Sloveniji

vodnik po upravnih storitvah, ki je lepo strukturiran in vsebinsko zapolnjen, tudi vsi obrazci za vloge so na voljo. Manjka pa seveda več transakcijskih storitev, ki bodo ponujenim informacijam dale pravo vrednost. Koristne so tudi javne objave, ki jih predstavljajo elektronske oglasne deske UE, in možnost posredovanja pripomb, predlogov in pohval, ki pa žal niso objavljene. Manjkajo tudi statistična poročila o delu in kakovosti dela UE.

Slika 2: Pogostost predstavljenih vsebin na spletiščih UE (v odstotkih)

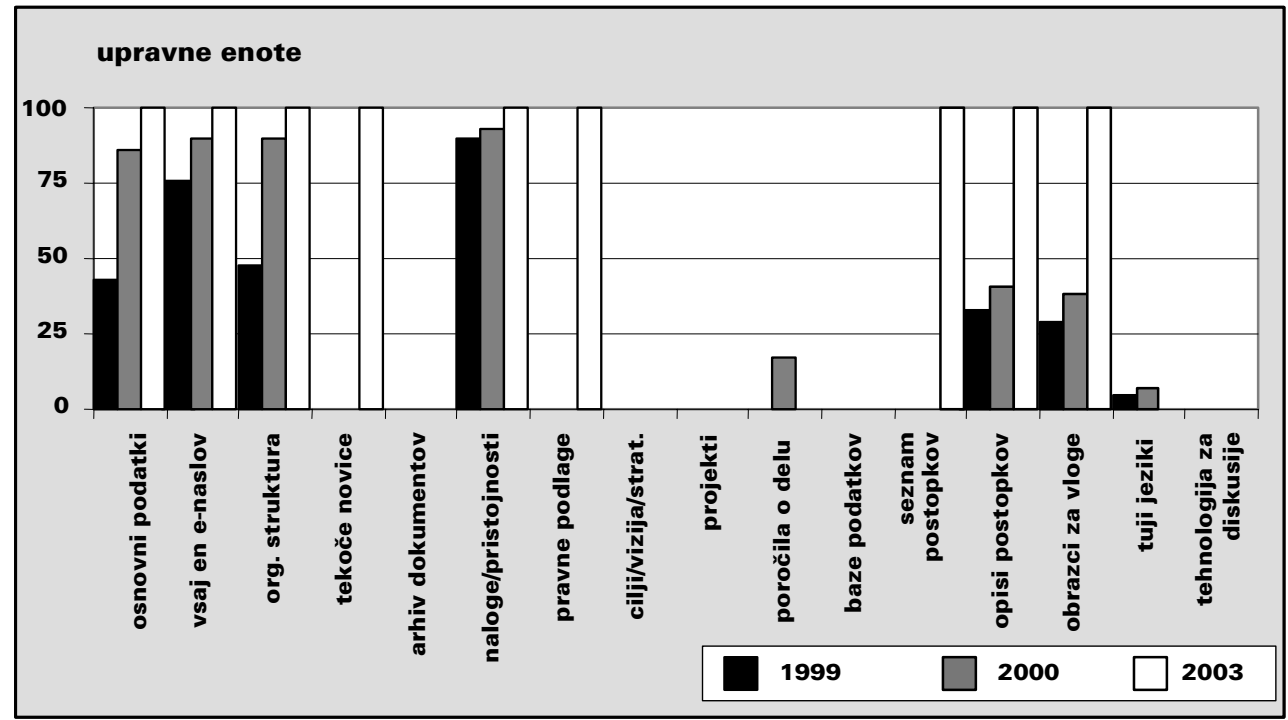

Tudi pri občinah (slika 3) opažamo rast pri vseh analiziranih vsebinah razen pri predstavitvi $\vee$ tujih jezikih, ki je v letu 2003 manjša kot $v$ letu 2000, verjetno zato, ker se spletne strani, ki se nanašajo na turizem in so $\vee$ pristojnosti lokalnih turističnih organizacij, vse bolj predstavljajo kot samostojna spletišča. Na grafikonu so desno od pokončne črte prikazane vsebine, ki smo jih analizirali samo na spletnih straneh občin in smo jih večinoma začeli meriti v letu 2000, nekaj pa v letu 2003. Žal povprečna občina na svojih spletnih straneh predstavlja le tretjino analiziranih vsebin, kar kaže na dokaj skromno predstavitev občin na spletu, vendar je treba upoštevati, da so spletišča večjih občin veliko bolj obsežna in tehnološko razvita kot spletišča manjših občin.

Osnovne podatke o občini, ki bi morali biti na vsakem spletišču objavljeni na prvem mestu, objavlja samo $42 \%$ občin, skoraj vse (92\%) pa ponujajo vsaj en elektronski naslov. Tudi ažurnost spletišč še ni na zadovoljivi ravni. 42 \% spletišč je sicer dnevno ažuriranih, vendar pa kar $22 \%$ občin ni ažuriranih niti enkrat na leto. Čeprav imajo občine veliko stikov z državljani in podjetji, nas preseneča dejstvo, da so upravni postopki, ki se strankam kažejo $v$ obliki storitev, izjemno slabo 
predstavljeni. Nobena občina namreč ne predstavlja seznama storitev, samo $3 \%$ pa urejen seznam postopkov. Sicer pa $28 \%$ občin predstavlja vsaj nekaj informacij o vsaj enem upravnem postopku, nobena pa ne opisuje več kot 10 postopkov, kar je glede na število upravnih postopkov $\vee$ pristojnosti občin zelo skromna številka. Precej več občin (52 \%) pa objavlja vsaj en obrazec za vlogo, vendar jih v veliki večini $(99 \%)$ ni mogoče oddati v elektronski obliki. Zanimivo pa ena občina omogoča spremljanje postopkov prek interneta ali SMS sporočil.

\section{Slika 3: Pogostost predstavljenih vsebin na spletiščih občin (v odstotkih)}

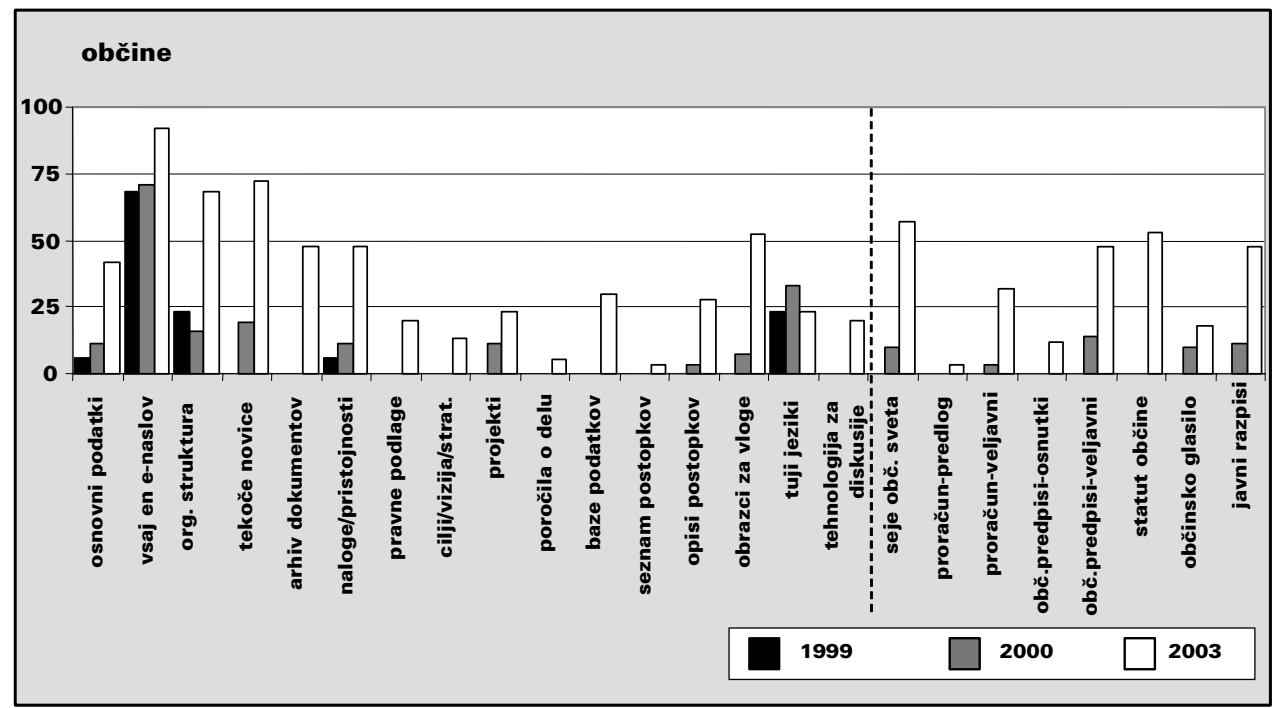

Analiza vsebin spletišč ministrstev (slika 4) kaže porast pogostosti predstavljenih vsebin. Tudi ažurnost teh vsebin je dobra. Presenetljivo je, da zelo malo ministrstev objavlja osnovne podatke (predvsem na račun uradnih ur), vsa pa ponujajo vsaj en elektronski naslov za možnost komuniciranja. Nobeno ministrstvo nima objavljenega abecednega seznama storitev ali postopkov, $79 \%$ pa jih objavlja opis vsaj enega postopka, kar kaže na to, da vsebine spletišč še vedno niso oblikovane na podlagi potreb uporabnikov, temveč na podlagi notranjih potreb ministrstev. Skoraj tri četrtine (71\%) ministrstev objavlja tudi obrazce za vloge, pri čemer le dve omogočata tudi njihovo elektronsko oddajo.

Gledano na splošno, rezultati raziskav kažejo, da se spletne strani posameznih upravnih organizacij hitro razvijajo tako glede same tehnološke zasnove kot glede obsega in raznolikosti informacij. V splošnem kažejo spletne strani občin precej slabšo sliko kot portal UE in spletne strani ministrstev. Treba pa je poudariti, da so slabše razvite predvsem manjše občine, te pa zaradi številčnosti močno vplivajo na končne ocene. 
Slika 4: Pogostost predstavljenih vsebin na spletiščih ministrstev (v odstotkih)

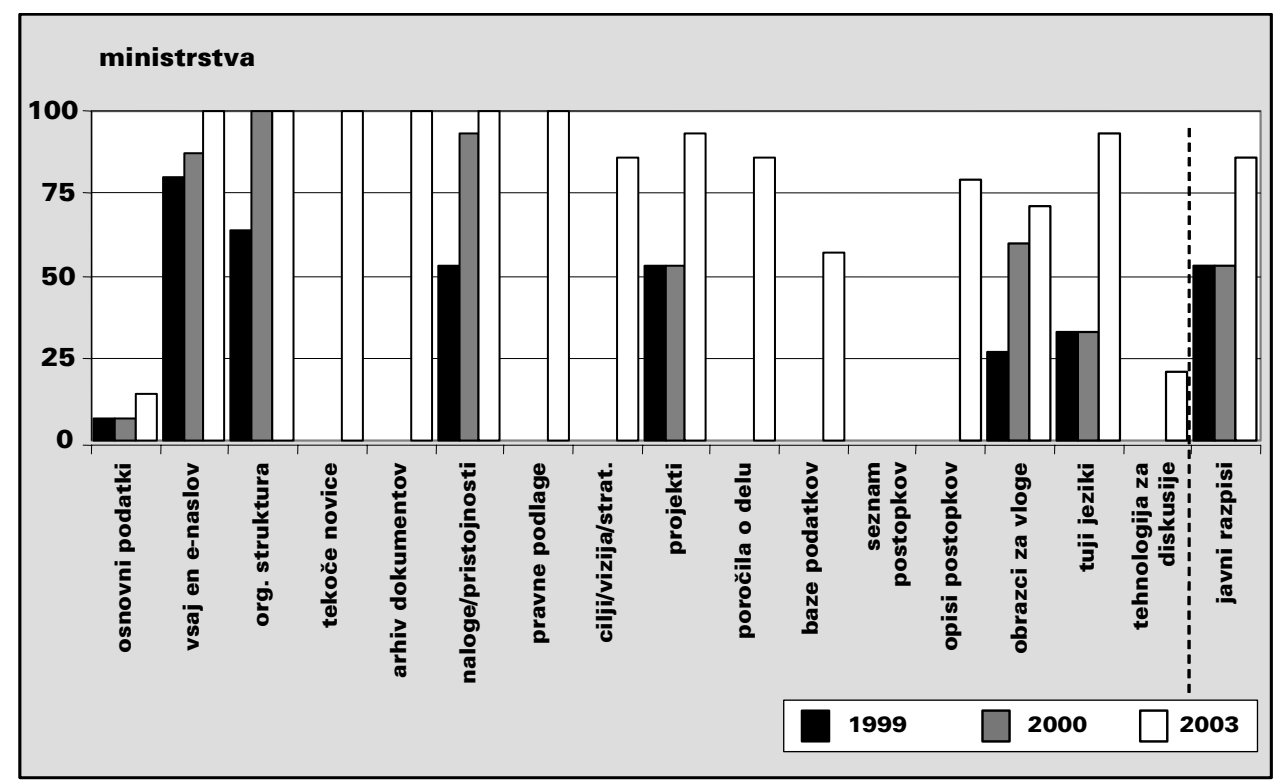

$V$ skladu z vedno večjim obsegom informacij na spletnih straneh pa so vedno boljše, čeprav še vedno nezadovoljive, tudi navigacijske možnosti oz. načini iskanja informacij in storitev po spletiščih (slika 5).

Rezultati raziskave kažejo, da sta struktura in dostop do vsebin na vseh spletiščih, razen na portalu UE, še vedno zasnovana na podlagi notranjih potreb in notranje organiziranosti posameznih organov, ne pa na osnovi potreb uporabnikov informacij in storitev.

Stanje je slabo tudi na področju tehnološke razvitosti storitev. Ne samo, da razen UE niti ministrstva niti občine na svojih spletnih straneh ne objavljajo informacij o vseh svojih storitvah, ampak so tudi storitve, ki so dostopne prek spleta, s tehnološkega vidika večinoma le na informacijski stopnji razvoja, saj so na voljo predvsem informacije in nekaj obrazcev za shranjevanje ali tiskanje, interakcijskih storitev, kjer bi bilo mogoče vlogo oddati po elektronski poti, pa je še vedno le peščica. Tako pri UE kot pri ministrstvih in občinah pa ne zasledimo nobenega primera transakcijskih storitev, kjer celotna komunikacija z uporabnikom storitve (oddaja vloge in prejem rešitve) poteka po elektronski poti.

Upravni organi tudi premalo spodbujajo možnost sodelovanja državljanov pri oblikovanju politike in zakonodaje, saj so projekti, osnutki predpisov in e-forumi na voljo le v posameznih primerih (sliki 3 in 4). 


\section{Slika 5: Načini iskanja informacij in storitev na spletiščih različnih} upravnih organizacij v letu 2003

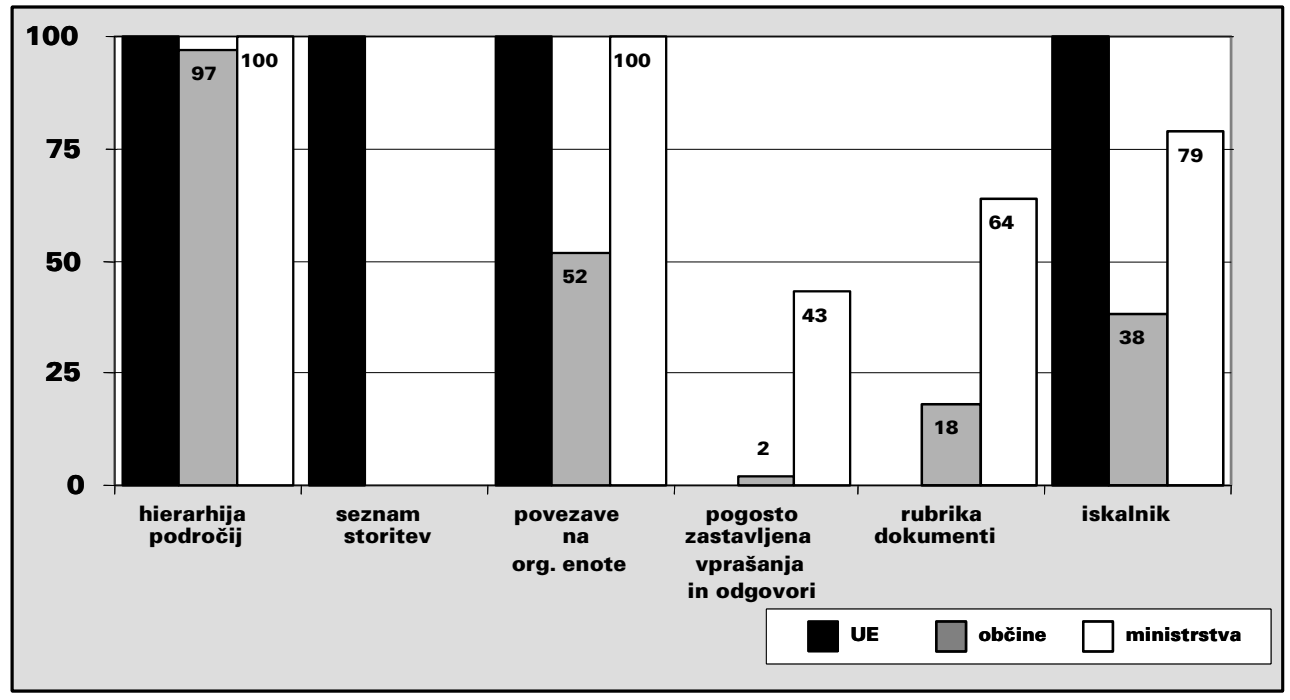

\section{Odzivnost}

S preskusom odzivnosti ugotavljamo hitrost in vsebino odziva na realno vprašanje izmišljenega občana, poslanega po e-pošti ${ }^{\mathbf{3}}$. Rezultati kažejo (slika 6), da se odzivnost UE in občin (OBč) z leti sicer manjša, vendar menimo, da je to posledica vzorca analiziranih organizacij, saj smo šele v letu 2003 v analizo zajeli vse UE in občine. $V$ prejšnjih letih smo vprašanje po e-pošti poslali samo tistim, ki so imeli na svojih spletnih straneh objavljene e-naslove. Predvidevamo, da so se tudi bolj zavedali pomembnosti komuniciranja po elektronski poti in da je bil zato odstotek tistih, ki so tudi odgovorili na zastavljeno vprašanje, v preteklih letih višji kot v letu 2003. Če upoštevamo skupno število UE in skupno število občin v posameznem letu, pa odzivnost narašča, in sicer od 33 \% v letu 2000 do 69 \% v letu 2003 pri UE in od $16 \%$ do $32 \%$ pri občinah. Že od vsega začetka pa so bili v preskus vključeni vsa ministrstva (MIN) in poslanci državnega zbora (DZ). Tudi v tem primeru rezultati kažejo vsakoletno izboljšanje odzivnosti.

3 Primeri vprašanj za posamezne tipe organov so naslednji:

- $\quad$ ministrstva: "Zanima me, kako bi lahko prišel do osnutkov zakonov, ki jih pripravljate na vašem ministrstvu?"

- $\quad$ upravne enote in občine: "Na parceli, ki leži na območju vaše upravne enote/občine, želim graditi hišo, pa ne vem, če je zazidljiva. Zanima me, kakšen je postopek za pridobitev te informacije in če to lahko uredim preko e-pošte?"

- $\quad$ državni zbor: "Zanima me ali lahko kot državljan prisostvujem sejam državnega zbora kot gledalec v parlamentu in kakšni so pogoji?" 
Kunstelj, Leben

Trendi razvoja e-uprave

Rezultati tudi kažejo, da se je večina organov odzvala v prvih 3 dneh (slika 6), kar je dobro, slabo pa je, da stoodstotne odzivnosti, ki je $\vee$ navadi pri klasičnem načinu poslovanja, še ni na vidiku. To slabost bo treba čim prej odpraviti, saj so organi po Zakonu o splošnem upravnem postopku (Uradni list RS št. 80/1999, 70/2000, 52/2002, 73/2004) dolžni odgovoriti na vloge občana, tudi če so posredovane po elektronski poti.

Slika 6: Odzivnost na vprašanje občana, poslanega po e-pošti (številke znotraj stolpcev kažejo odzivnost po posameznih dneh, številke na vrhu stolpcev pa končno odzivnost organa $v$ posameznem letu)

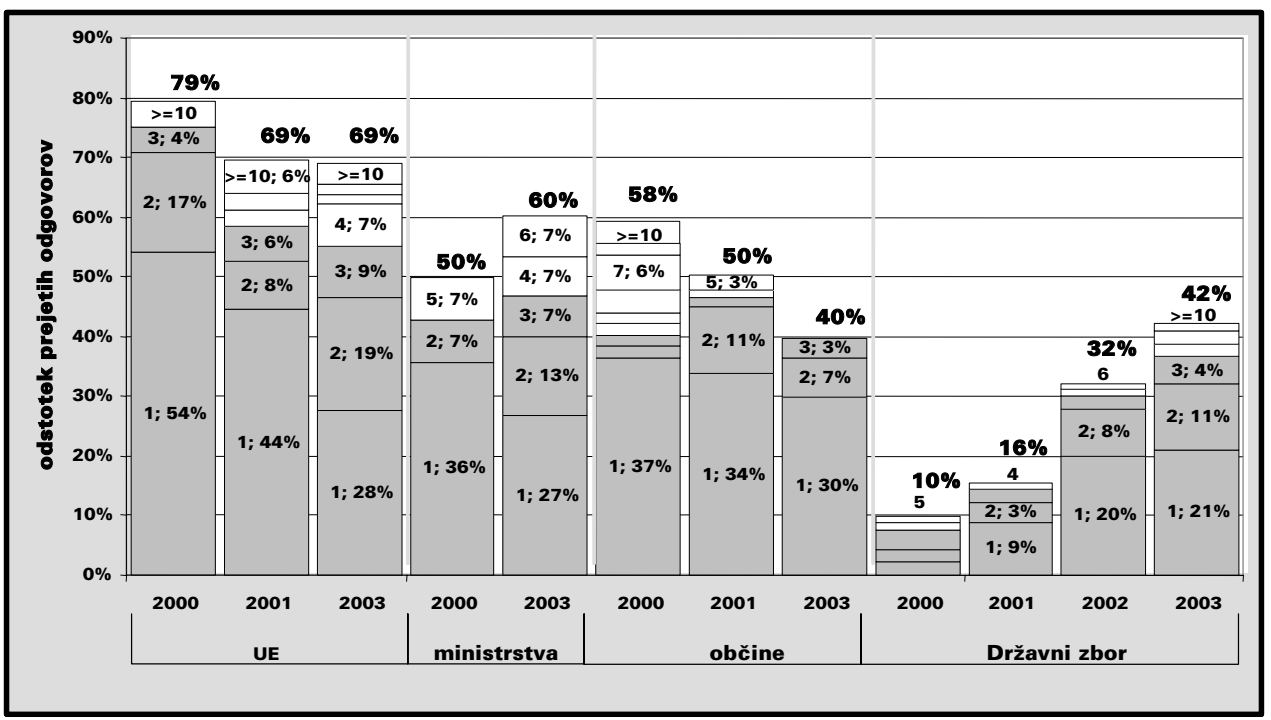

\section{Analiza 20 osnovnih javnih storitev}

Na podlagi metodologije Evropske komisije, ki v okviru programa eEurope $v$ državah članicah spremlja razvoj ponudbe elektronskih storitev uprave na internetu, smo podobno analizo opravili tudi $v$ Sloveniji. Metodologija temelji na merjenju razvitosti 20 storitev, ki naj bi predstavljale vzorčne primere storitev na področju e-uprave. Storitve se ocenjujejo s pomočjo 4-stopenjskega modela (preglednica 3), kjer nam stopnja razvitosti elektronske storitve pove, kako daleč $v$ razvoju k popolni elektronski obravnavi na spletu je posamezna storitev. Pri tem je bila za nekatere storitve (zaradi njihovih lastnosti) določena najvišja možna stopnja razvitosti 3 (osebni dokumenti, prijava policiji, izpiski iz matičnih knjig, sprememba bivališča in posredovanje statističnih podatkov). S povprečjem ocen teh storitev pa se oceni odstotek osnovnih javnih storitev na spletu v posamezni državi. 
Preglednica 3: 4-stopenjski model ocenjevanja razvitosti e-storitev uprave

\begin{tabular}{|c|c|c|c|}
\hline stopnj & $\%(\max =4)$ & $\%(\max =3)$ & opredelitev \\
\hline 0 & $0-24 \%$ & $0-32 \%$ & ni javno dostopnega spletišča z značilnostmi stopenj 1-4. \\
\hline 1 & $25-49 \%$ & $33-66 \%$ & $\begin{array}{l}\text { informacija - zajema možnost pridobitve različnih informacij o } \\
\text { posamezni storitvi na javno dostopnem spletišču: npr. infor- } \\
\text { macije, potrebne za sprožitev postopka, ki zagotavlja določeno } \\
\text { storitev. }\end{array}$ \\
\hline 2 & $50-74 \%$ & $67-99 \%$ & $\begin{array}{l}\text { interakcija - predvideva možnost shranjevanja in tiskanja } \\
\text { obrazcev, potrebnih za sprožitev storitvi pripadajočega postop- } \\
\text { ka - obrazce shranimo, nato pa jih bodisi izpolnimo s pomočjo } \\
\text { računalnika in natisnemo ali natisnemo in potem ročno izpol- } \\
\text { nimo, kar je odvisno od vrste obrazca. } V \text { tej stopnji je } \\
\text { upoštevana tudi možnost elektronskega naročanja na papirni } \\
\text { obrazec. }\end{array}$ \\
\hline 3 & $75-99 \%$ & $100 \%$ & $\begin{array}{l}\text { dvosmerna interakcija - javno dostopno spletišče omogoča } \\
\text { uporabo interaktivnih spletnih obrazcev za sprožitev storitvi } \\
\text { pripadajočega postopka in vključuje tudi enega izmed načinov } \\
\text { overjanja (fizična ali pravna avtentikacija). }\end{array}$ \\
\hline 4 & $100 \%$ & / & $\begin{array}{l}\text { transakcija - javno dostopno spletišče omogoča popolno elek- } \\
\text { tronsko obravnavo storitve, vključno z odločanjem, dostavo } \\
\text { končnega rezultata in plačilom, če je to potrebno. S tem za } \\
\text { uporabnika odpadejo vsi postopki papirnega poslovanja. }\end{array}$ \\
\hline
\end{tabular}

Vir: Cap Gemini Ernst \& Young, 2004

Rezultati raziskave za leto 2003 kažejo na izboljšanje rezultatov iz leta 2002, vendar ne bistveno (sliki 7 in 8). Med najbolj razvite storitve sodijo pridobitev rojstnega in poročnega lista, storitve javnih knjižnic in iskanje zaposlitve.

$\checkmark$ povprečju so slovenske storitve na prvi (informacijski) stopnji razvoja, to je več kot $20 \%$ za povprečjem držav članic EU, kjer so storitve v povprečju razvite na stopnji interakcije. Pri tem so $\vee$ Sloveniji, ravno obratno kot $\vee$ EU, storitve za občane bolj razvite od storitev za podjetja, kar je precej nenavadno glede na dejstvo, da imajo podjetja precej več in pogosteje opravke z upravo kot občani. Razkorak pri storitvah za podjetja je tako kar $42 \%$, medtem ko pri storitvah za občane Slovenija le rahlo zaostaja za EU. 
Kunstelj, Leben

Trendi razvoja e-uprave v Sloveniji

Slika 7: Razvitost 20 osnovnih javnih storitev v Sloveniji

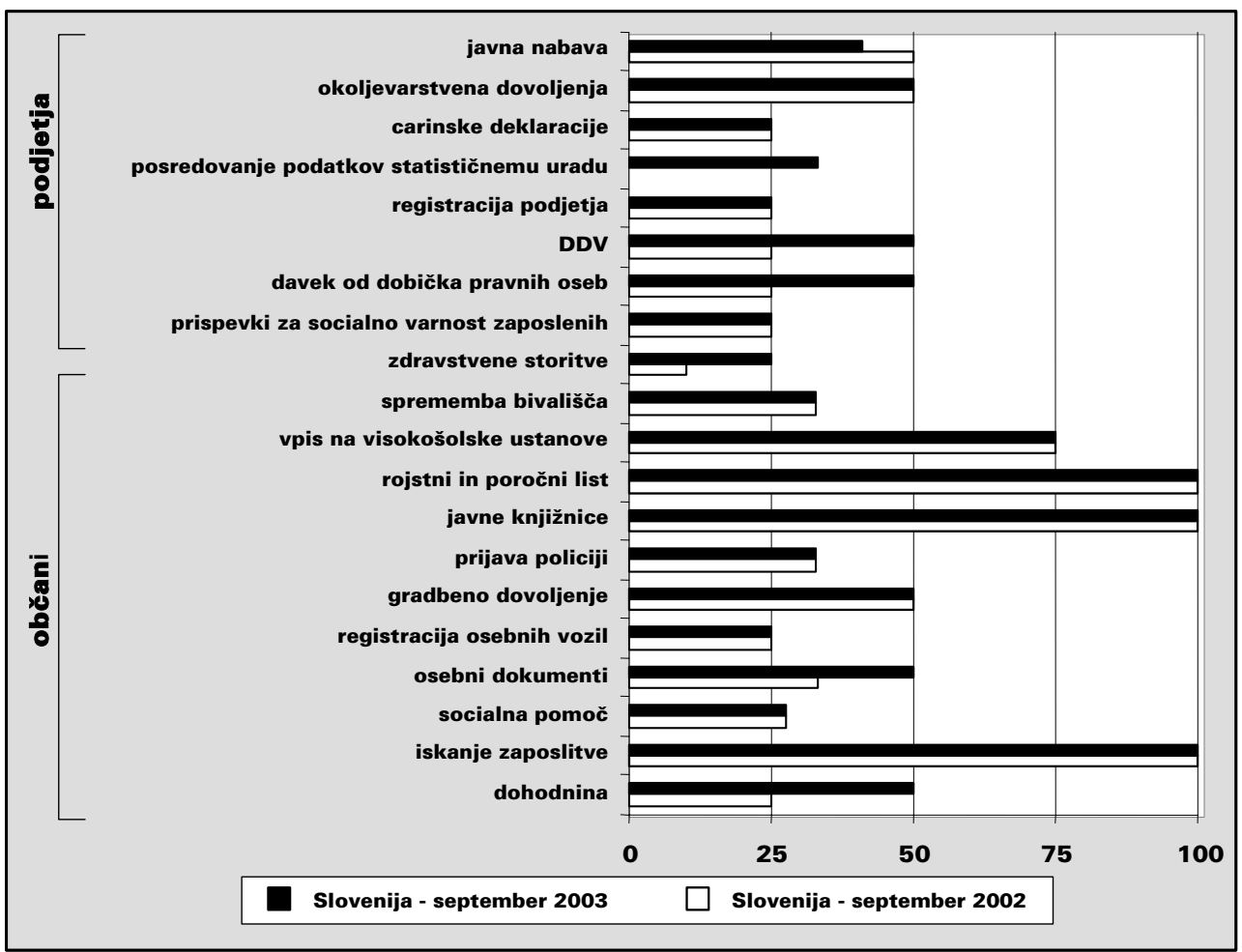

Slika 8: Povprečna razvitost osnovnih javnih storitev za podjetja in občane

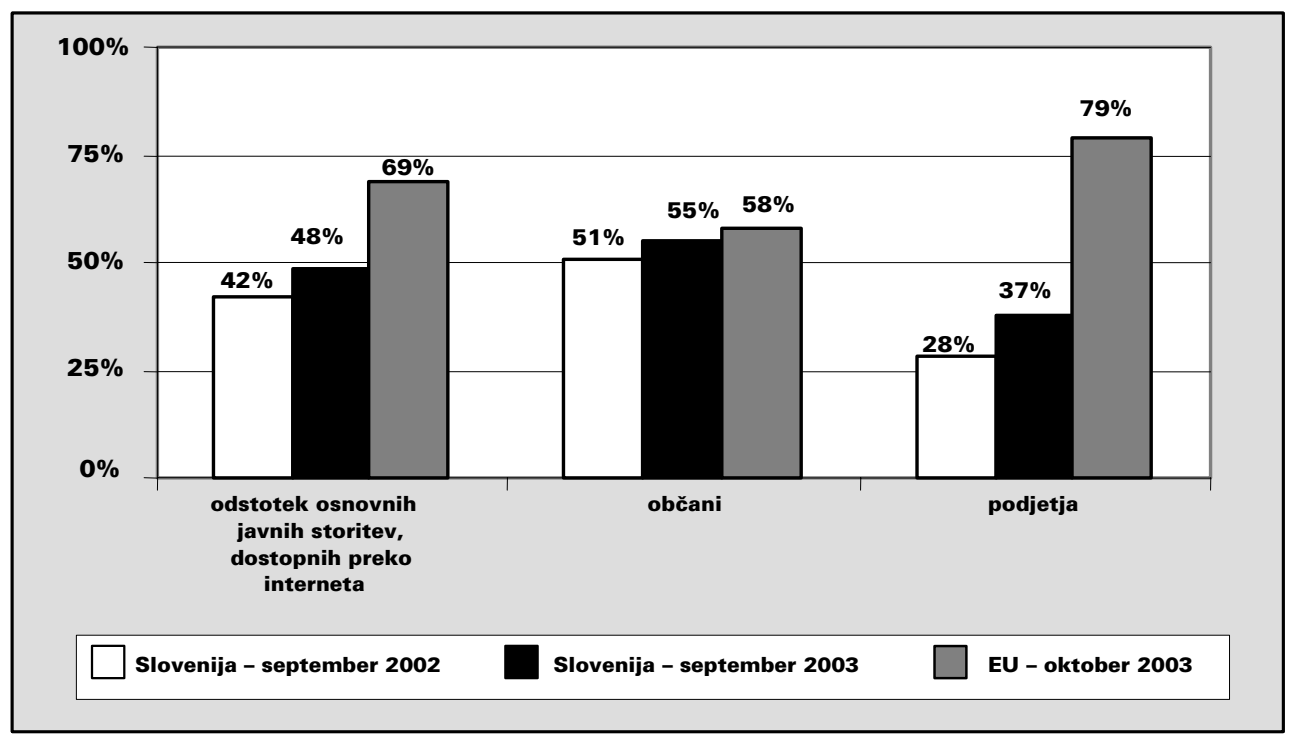




\section{Državni portal e-Uprava}

\subsection{Metodologija vrednotenja portalov življenjskih situacij}

Vrednotenje poteka na treh ravneh, ki ustrezajo trem osnovnim sestavinam portala. Vsak portal življenjskih situacij ( $v$ nadaljevanju PŽS) namreč podpira eno ali več življenjskih situacij. Na oceno PŽS kot celote zato vplivajo ocene posameznih življenjskih situacij, ki jih ovrednotimo na drugi ravni modela. Tudi ta raven je dodatno razgrajena, saj vsaka življenjska situacija zajema eno ali več storitev; te ocenjujemo na tretji ravni. $\vee$ celoti ima torej model tri ravni, ki omogočajo vrednotenje in analizo:

1. elektronskih storitev, ki so zajete $\vee$ posamezni življenjski situaciji;

2. življenjskih situacij ter

3. portalov življenjskih situacij $\vee$ celoti.

Do skupne ocene PŽS pridemo z združevanjem ocen, dobljenih na nižjih ravneh modela. Takšen način združevanja je preprost in pregleden, predvsem pa omogoča primerjalno analizo portalov posebej za elektronske storitve, življenjske situacije in PŽS kot celoto. Vrednotenje na posamezni ravni izvedemo z večparametrskimi modeli, ki so sestavljeni iz kriterijev, urejenih $\vee$ hierarhijo (najpogosteje drevo), in pravil združevanja (podrobneje glej Leben in Bohanec, 2004). Slika prikazuje shemo tristopenjskega modela kriterijev, ki smo jih upoštevali pri oceni portalov. Vsak model je sestavljen iz drevesa kriterijev, od katerih so nekateri osnovni (jih neposredno vrednotimo $z$ ustreznimi ocenami), ostali pa so izpeljani oz. agregirani (njihovo oceno določimo iz ocen za kriterije na nižji ravni ob upoštevanju pravil združevanja, ki so določena za vsak izpeljani kriterij posebej). Kriteriji v teh drevesih predstavljajo značilnosti entitete (storitve, življenjske situacije ali portala), ki jo želimo oceniti, ocena za kriterij na najvišji ravni posameznega modela pa predstavlja končno oceno za entiteto.

\section{Slika 9: Shematski prikaz značilnosti za ocenjevanje portalov življ. situacij}

\begin{tabular}{|c|c|c|}
\hline ocena portala & & \\
\hline \multirow{7}{*}{$\begin{array}{l}\text { način reševanja Žs } \\
\text { pokritost portala } \\
\text { uporabniški vidiki } \\
\text { dostop do Žs } \\
\text { seznam Žs } \\
\text { hierarhija področij } \\
\text { iskalnik } \\
\text { enotnost } \\
\end{array}$} & ocena Žs & \multirow{7}{*}{ 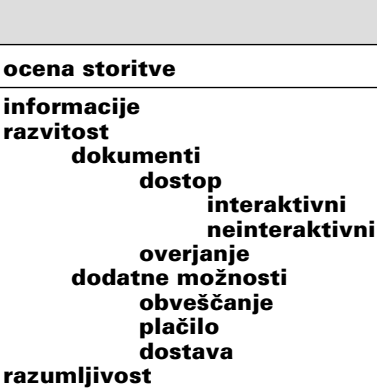 } \\
\hline & \multirow{5}{*}{$\begin{array}{l}\text { zrelost } \\
\text { razvitost Žs } \\
\text { pokritost Žs } \\
\text { koordiniranost } \\
\text { vidiki uporabe } \\
\text { dostop do storitev } \\
\text { ključne aktivnosti } \\
\text { opomnik } \\
\text { pogosta vprašanja } \\
\text { vodnik } \\
\text { enotnost storitev } \\
\text { razumljivost Žs }\end{array}$} & \\
\hline & & \\
\hline & & \\
\hline & & \\
\hline & & \\
\hline & & \\
\hline
\end{tabular}




\section{Kunstelj, Leben}

\section{Trendi razvoja e-uprave v Sloveniji}

Omeniti moramo, da smo predvsem pri analizi življenjskih situacij (v nadaljevanju ŽS) in portala kot celote upoštevali le tiste kriterije, ki so značilni za oblikovanje in ponudbo storitev, zasnovanih okrog življenjskih situacij. Pri oceni storitev smo deloma izhajali iz opredelitve stopnje razvitosti storitve (Cap Gemini Ernst \& Young, 2004), pri čemer smo ocenjevali posamezne kriterije, ki določajo stopnjo razvitosti, posebej pa smo ocenjevali še razumljivost storitve. Pri ŽS smo poleg ocene za razvitost ŽS (ki jo izračunamo na podlagi ocen storitev $\vee$ okviru posamezne ŽS) upoštevali še pokritost ŽS s storitvami, stopnjo koordiniranosti storitev v okviru ŽS ter različne uporabniške vidike ŽS. Skupno oceno za portal dobimo iz ocen za način reševanja ŽS (izračunana je iz ocen analiziranih ŽS), pokritost portala (s tematskimi področji in $\breve{Z} S$ ) ter uporabniške vidike portala $\vee$ celoti.

\subsection{Rezultati}

Analizo slovenskega državnega portala smo opravili v okviru širše raziskave portalov življenjskih situacij v avgustu 2002 in juniju 2003 (Leben in drugi, 2004), ter $\vee$ septembru 2004. Ker smo $\vee$ okviru omenjene raziskave primerjali več portalov (večinoma iz evropskih držav), smo kot osnovo za analizo in vrednotenje izbrali štiri življenjske situacije: selitev, izdaja potnega lista, izdaja vozniškega dovoljenja in odpiranje podjetja. $\vee$ tem prispevku predstavljamo le rezultate meritev za slovenski državni portal e-uprava ${ }^{4}$.

Levi grafikon na sliki 10 prikazuje primerjavo ocen značilnosti za vrednotenje portala ŽS kot celote na slovenskem državnem portalu e-uprava. Debelejše pokončne črte označujejo najvišjo možno oceno za posamezno značilnost. Enotnost ŽS (ki ocenjuje, kako enotno so ŽS na portalu predstavljene) je pri drugi meritvi dosegla najboljšo možno oceno, značilnost dostop do ŽS na portalu (ki ocenjuje različne možnosti dostopa do ŽS oz. navigacije po portalu) pa je dosegla drugo najvišjo možno oceno; obe oceni sta se glede na prvo meritev izboljšali za dve stopnji.

Pokritost in reševanje ŽS sta v letu 2003 dosegla za stopnjo boljši oceni. Pokritost portala je dosegla srednjo vrednost, saj portal $\vee$ letu 2003 še ni ponujal zadostnega števila življenjskih situacij, portal pa tudi ne pokriva vseh tematskih področij, ki smo jih opredelili kot obvezna. V letu 2004 je to edina značilnost, ki je dosegla višjo oceno kot v letu 2003, saj sta tako pokritost portala z ŽS kot s tematskimi področji dosegli najvišjo možno oceno. Višja ocena za pokritost je tudi vzrok za višjo skupno oceno portala v celoti.

4 http://e-uprava.gov.si/e-uprava/ 
Slika 10: Primerjava ocen za portal e-uprava: značilnosti, ki ocenjujejo portal v celoti (levo), in končne ocene za analizirane Žs (desno)

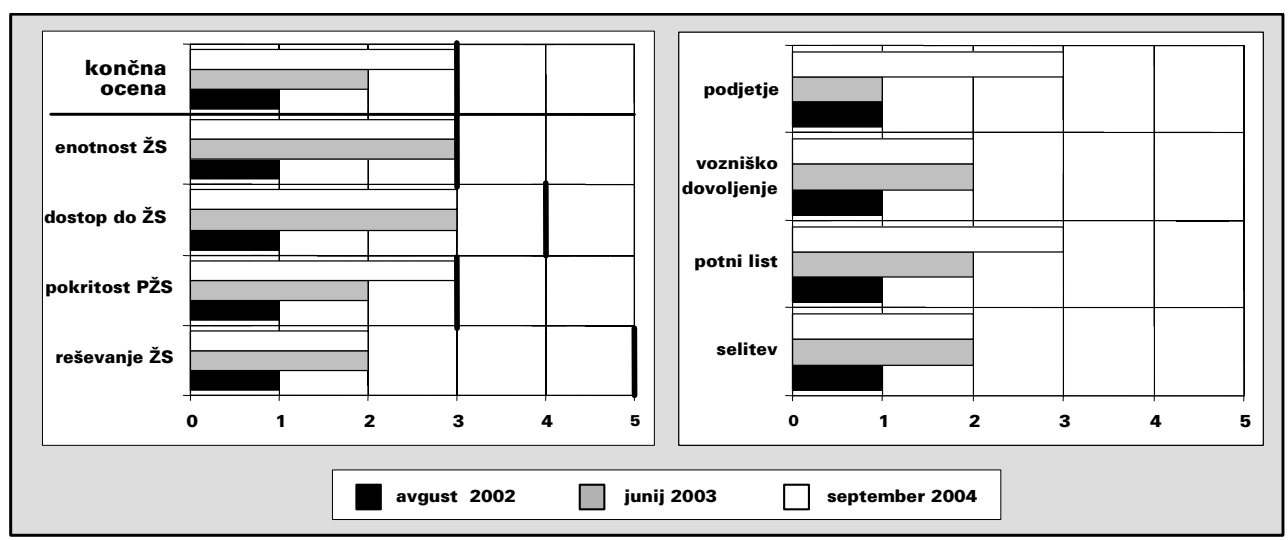

Višja ocena za reševanje ŽS v letu 2003 je posledica višjih končnih ocen analiziranih situacij na portalu, saj so kar tri situacije od štirih dosegle za eno stopnjo višjo oceno (slika 10 - desno). To so situacije, ki neposredno posegajo na področje delovanja UE (selitev, izdaja potnega lista in izdaja vozniškega dovoljenja), zato so tudi te ocene posledica vpeljave portala UE. Ocena za odpiranje podjetja se je izboljšala kar za dve stopnji, kar gre pripisati vpeljavi spletišča Pospeševalnega centra za malo gospodarstvo ${ }^{\mathbf{5}}$. Dobra strukturiranost spletišča in obilo informacij sta pripomogla $\mathrm{k}$ višjim ocenam za uporabniške vidike $\breve{Z} S$, izboljšali pa sta se tudi stopnja koordiniranosti in razumljivosti ŽS. Ocena za izdajo potnega lista se je izboljšala za eno stopnjo prav tako zaradi višje ocene za uporabniške vidike, $k$ čemur je pripomogla dobro oblikovana in izčrpna rubrika 'pogosto zastavljena vprašanja'.

Slika 11: Primerjava povprečnih ocen za značilnosti, ki ocenjujejo Žs na portalu e-Uprava

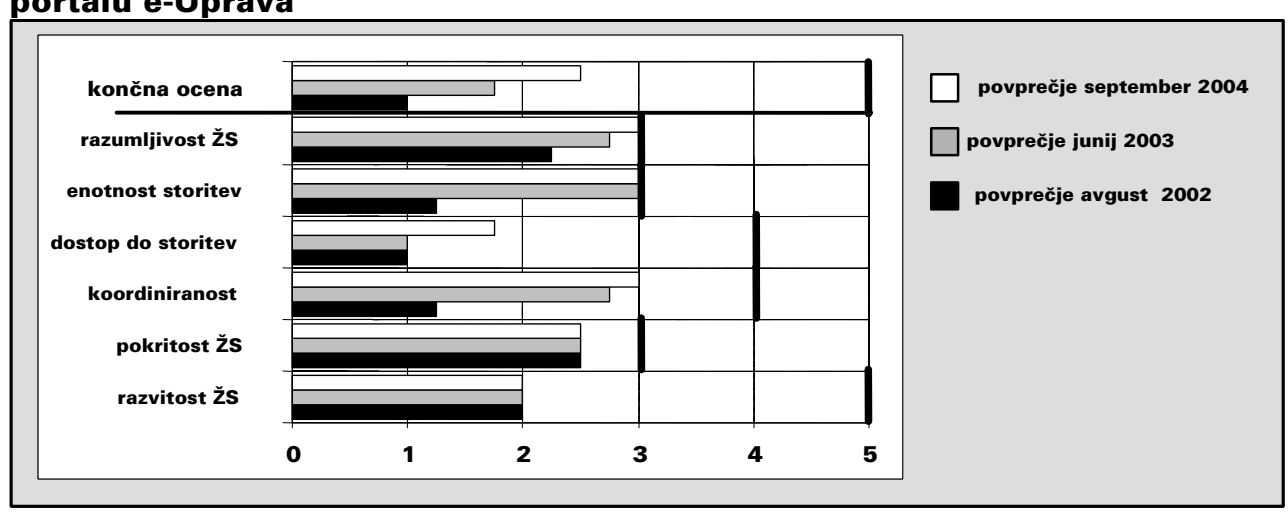

5 http://www.pcmg.si 


\section{Kunstelj, Leben \\ Trendi razvoja e-uprave v Sloveniji}

Grafikon na sliki 11 prikazuje primerjavo povprečnih ocen značilnosti za vrednotenje ŽS na portalu e-uprava. Tudi tu debelejše pokončne črte označujejo najvišjo možno oceno. Posamezne značilnosti, predstavljene na grafikonu, imajo naslednji razpon ocen:

- razumljivost ŽS, enotnost storitev in pokritost ŽS: 1 - neprimerno, 2 - manj primerno, 3 - primerno;

- dostop do storitev: 1 - neustrezno, 2 - delno ustrezno, 3 - ustrezno, 4 - zelo ustrezno;

- stopnja koordiniranosti: 1 - razpršenost (za neko ŽS moramo storitve poiskati na različnih spletiščih ali na različnih spletnih straneh znotraj spletišča), 2 - ena vstopna točka (do storitev sicer pridemo preko iste vstopne točke, ki pa nudi le povezave do spletnih strani ustreznih institucij, ki storitve izvajajo) , 3 - korak za korakom (storitve so sicer zbrane na enem samem mestu, vendar moramo prožiti vsako posebej), 4 - en korak (storitve so zbrane na enem mestu, uporabnik sproži le prvo, vse ostale pa se prožijo samodejno ali jih proži institucija sama);

- razvitost ŽS in končna ocena za ŽS: 1 - nesprejemljivo, 2 - sprejemljivo, 3 - dobro, 4 - prav dobro, 5 - odlično.

Enotnost storitev je dobila najvišjo možno povprečje ocen že pri drugi meritvi, saj je bila ta značilnost pri vseh situacijah v letu 2003 ocenjena z najvišjo možno oceno $v$ nasprotju $s$ prvo meritvijo, kjer so vse situacije, razen izdaje vozniškega dovoljenja, dobile najnižjo možno oceno. $\vee$ zadnjih dveh meritvah sta se izboljšali povprečni oceni za razumljivost predstavitve ŽS in stopnjo koordiniranosti storitev $\checkmark$ ŽS. Stopnja koordiniranosti je v letu 2003 pri odpiranju podjetja ostala na ravni 'ene vstopne točke', pri ostalih treh situacijah pa je napredovala iz 'razpršenosti' do 'korak za korakom'; v letu 2004 pa je za vse štiri analizirane ŽS ocenjena kot 'korak za korakom'. Način dostopa do storitev je bil za vse situacije pri prvih dveh meritvah ocenjen z najnižjo možno oceno, stanje pa se je izboljšalo v letu 2004 pri situacijah izdajanje potnega lista in odpiranje podjetja.

Ocene za razvitost ŽS (določene iz ocen storitev znotraj posamezne situacije) so za vse situacije $v$ vseh treh letih dosegle oceno 'sprejemljivo' predvsem zaradi nizke razvitosti posameznih storitev. Vse značilnosti, ki vplivajo na razvitost storitve (glej sliko 9), so bile pri vseh storitvah ocenjene z najnižjo možno oceno. Izjema je le možnost shranjevanja obrazcev (neinteraktivni dostop do dokumentov), ki jo je pri zadnjih dveh meritvah ponujala polovica ocenjenih storitev. $\vee$ nasprotju z nizkimi ocenami za razvitost storitev pa je večina analiziranih storitev za ponujene informacije in razumljivost storitev dosegla najvišjo možno oceno.

\section{Uprava, letnik II, 2/2004}




\section{Kunstelj, Leben \\ Trendi razvoja e-uprave v Sloveniji}

\section{Končne ugotovitve}

Razveseljivo je, da se vse več upravnih organizacij predstavlja na spletu, marsikaj pa bo treba storiti glede vsebine spletnih predstavitev. Največ je bilo v letu 2003 storjenega pri predstavitvi UE in ministrstev, medtem ko predstavitev občin zaostaja tako pri odstotku predstavljenih občin na spletu kot tudi glede predstavljenih vsebin, vendar je treba upoštevati, da imajo večje občine precej bolj razvite spletne predstavitve od manjših. Ker je v okviru strategije e-občin (SEPLS, 2003) za leto 2004 načrtovana uvedba prve različice enotnega portala občin, upamo, da se bo stanje hitro izboljšalo. Zavedamo se, da je to za občine kot samostojne lokalne skupnosti teže izvedljivo kot npr. za upravne enote, vendar bi poenotene vsebine spletnih predstavitev uporabnikom olajšale iskanje informacij in dostop do upravnih storitev.

Spletišča so vedno bolj razvita, tudi vsebine so vsako leto bogatejše, navigacija po spletiščih pa še ni dovolj razvita, saj sta struktura in dostop do vsebin zasnovana na podlagi notranje organiziranosti in ne na osnovi potreb uporabnikov. Tudi ažurnost spletišč še ni na zadovoljivi ravni, predvsem pri občinah, ki nasploh kažejo slabšo razvitost. Upravni organi tudi premalo spodbujajo možnost sodelovanja državljanov v e-demokratičnih procesih.

Razen pri UE so nezadostno predstavljene tudi upravne storitve. Poleg tega je možnost elektronske oddaje vloge še vedno redka, $v$ nobenem primeru pa ne zasledimo popolne elektronske podprtosti storitev in pripadajočih upravnih postopkov.

Upoštevajoč skupno število UE, se odzivnost na vprašanje občana, zastavljeno po e-pošti, pri UE sicer izboljšuje, vendar pa 69 \% prejetih odgovorov v letu 2003 po našem mnenju ne zadostuje, saj menimo, da bi morala biti odzivnost $100 \%$, tako kot je navada $v$ klasičnem papirnem poslovanju. Upravni organi so namreč po Zakonu o splošnem upravnem postopku dolžni odgovoriti na vlogo občana, tudi če je zastavljena po elektronski poti. Naloga UE in pristojnih ministrstev je, da stanje popravijo. Poleg tega lahko UE pričakujejo drastično povečanje takih in podobnih elektronskih sporočil, ko se bosta splošna raven družbe $\vee$ Sloveniji in njena računalniška pismenost še povečali. Zato je treba na to misliti že danes in ustrezno ukrepati. Tudi pri občinah se odzivnost izboljšuje, vendar je bilo stanje v letu 2003 zelo zaskrbljujoče, saj je na vprašanje občana, zastavljeno po e-pošti, odgovorilo le $40 \%$ občin, ki so prejele vprašanje. Glede na to, da so bili spletni naslovi objavljeni na spletnih straneh občin oziroma na občinskem portalu Obcine.net ${ }^{\mathbf{6}}$, smo pričakovali boljše rezultate. Torej občine čaka še zelo veliko dela pri izboljšanju odnosa zaposlenih do komuniciranja z občani po elektronski poti. Upamo, da bo

$6 \mathrm{http}: / / \mathrm{www}$.obcine.net 


\section{Kunstelj, Leben}

\section{Trendi razvoja e-uprave v Sloveniji}

80 \% občin (Vintar in ostali 2003a), ki načrtujejo interna navodila in standarde, določilo tudi, da je treba na vsako e-sporočilo odgovoriti.

Pri državnem zboru (kjer že od leta 1999 pošiljamo vprašanja vsem poslancem) se odzivnost iz leta $v$ leto izboljšuje. Če pa upoštevamo, da je 84 \% poslancev v letu 2003 vprašanje prebralo, nanj pa je odgovorilo le $42 \%$ poslancev (torej polovica tistih, ki so vprašanje prebrali), lahko rečemo, da je stopnja zavedanja odgovornosti objave elektronskega naslova in ustrezne kulture zaenkrat še na nizkem nivoju. Upamo pa lahko, da se bo trend povečevanja odzivnosti poslancev nadaljeval in da bo e-pošta postala in ostala pomemben način stika med volivci in voljenimi.

Pohvaliti velja razvijalce slovenskega državnega portal e-Uprava, saj se končne ocene za portal stalno izboljšujejo. Velik napredek je bil dosežen v letu 2003, ko so vse značilnosti ocenjevanja portala dosegle višjo oceno kot v letu 2002. Izrazito izboljšanje ocen za enotnost predstavitve ŽS in mehanizmov dostopa do ŽS v letu 2003 je posledica vpeljave portala UE, ki je po našem mnenju dobro zasnovan. Vendar pa bo $v$ prihodnosti treba te mehanizme še izboljšati $z$ bolje zasnovanim iskalnikom in seznamom predstavljenih ŽS s kratkim opisom. Ta značilnost je v letu 2004 edina, ki poleg reševanja ŽS ni dosegla najvišje možne ocene. Na oceno za reševanje ŽS vplivajo ocene analiziranih ŽS. Primerjava teh ocen kaže v letu 2003 velik napredek pri zasnovi ŽS, v letu 2004 pa tudi rahel napredek pri oblikovanju načinov dostopa do storitev. Vendar pa razvijalce portala na tem področju čaka še veliko dela, prav tako tudi pri zagotavljanju čim višje stopnje tehnološke razvitosti e-storitev $v$ okviru ŽS, saj so analizirane storitve večinoma še vedno le informacijske. Večino storitev bi lahko oblikovali kot transakcijske, kar pomeni, da bi portal omogočal neposreden dostop do spletnih obrazcev, oddajo elektronskih dokumentov vključno z overjanjem pa tudi dodatne možnosti elektronskega poslovanja, kot so obveščanje, plačilo in dostava dokumentov (rezultatov izvedenih storitev) po elektronski poti.

Anamarija Leben je diplomirala s področja podatkovnega modeliranja; trenutno na Fakulteti za organizacijske vede Univerze $v$ Mariboru zaključuje magistrski študij s področja uporabe sistemov znanja v upravi. Od leta 1995 je zaposlena kot asistentka za področje informatike na Fakulteti za upravo Univerze $v$ Ljubljani, kjer se na raziskovalnem področju ukvarja z različnimi vidiki razvoja e-uprave.

Mateja Kunstelj je leta 1997 diplomirala, leta 2002 pa magistrirala s področja prenove procesov v upravi na Fakulteti za računalništvo in informatiko Univerze v Ljubljani. Zaposlena je kot asistentka za predmetno področje informatike na Fakulteti za upravo v Ljubljani, kjer se poleg pedagoškega dela ukvarja še z raziskovanjem različnih vidikov razvoja in uvajanja e-uprave.

\section{Uprava, letnik II, 2/2004}




\section{Kunstelj, Leben}

\section{Literatura in viri}

- $\quad$ Cap Gemini Ernst \& Young (2004): "Online Availability of Public Services: How is Europe Progressing? (Web-based survey on electronic public services: Report of the Fourth Measurement, October 2003)", European Commission DG Information Society, Brussels.

- $\quad$ eEurope2005 (2002): eEurope 2005: An information society for all. European Commission. http://europa.eu.int/information_society/eeurope/2002/news_library/documents/eeurope 2005/eeurope2005_en.pdf

- $\quad$ Kunstelj, M. (2004): "Kratek pregled razvoja e-uprave". E-uprava: izbrane razvojne perspektive (Vintar, M. in Grad, J., ur.), Fakulteta za upravo, Ljubljana, str. 15-36.

- Kunstelj, M., Dečman, M. (2004): Development of E-government in Slovenian Local Self-government. Proceedings of the 4th European Conference on e-Government 'Towards Innovative Transformation in the Public Sector', ECEG 2004 (Remenyi, D., ur.). Department of the Taoiseach of the Republic of Ireland, Dublin. tr. 419-430.

- Leben, A., Kunstelj, M., Bohanec, M. (2004): Evaluation of Life-Event Portals: Trends in Developing e-Services Based on Life-Events. Proceedings of the 4th European Conference on e-Government 'Towards Innovative Transformation in the Public Sector', ECEG 2004 (Remenyi, D., ur.). Department of the Taoiseach of the Republic of Ireland, Dublin, str. 469-480.

- Leben, A., Bohanec, M. (2004): "Vrednotenje portalov življenjskih situacij". E-uprava: izbrane razvojne perspektive (Vintar, M. in Grad, J., ur.), Fakulteta za upravo, Ljubljana, str. 123-140

- $\quad$ Lenk, K. in Traunmüller, R. (2002): "Electronic Government: Where Are We Heading?". Proceedings of the First International Conference, EGOV 2002 (Traunmuller, R. in Lenk, K., ur.), Springer-Verlag Berlin Heidelberg, str. 1-9.

- Vintar, M., Dečman, M., Kunstelj, M. (1999): Telematics in the service of democracy: The Slovenian parliament and other Slovenian public institutions on the internet. Parliamentary Affairs. Let. 52, št. 3, str. 451-463.

- Vintar, M., Kunstelj, M., Dečman, M. (2000a): Analiza stanja pri uporabi interneta v javnem sektorju. VII. Dnevi slovenske uprave 2000, zbornik referatov. Visoka upravna šola, Ljubljana. Str. 305-324.

- Vintar, M., Bohanec, M., Dečman, M., Kunstelj, M., Leben, A., Berčič, B. (2002b): Razvoj inteligentnega portala na osnovi življenjskih situacij. 1. letno poročilo - poročilo raziskovalne faze. Visoka upravna šola, Ljubljana.

- Vintar, M., Kunstelj, M., Dečman, M., Berčič, B. (2002): Kako daleč smo z e-upravo? IX. Dnevi slovenske uprave 2002, zbornik referatov. Visoka upravna šola, Ljubljana. Str. 421-441. 


\section{Trendi razvoja e-uprave v Sloveniji}

- Vintar, M., Dečman, M., Kunstelj, M., Leben, A., Berčič, B. (2003a): Razvoj sistema merjenja rabe IT $\vee$ javnem sektorju $\vee$ Sloveniji: končno poročilo internega projekta. Fakulteta za upravo, Ljubljana.

- Vintar, M., Kunstelj, M., Dečman, M. in Berčič, B. (2003b): "Development of e-government in Slovenia" Information Polity, let. 8, št. 3/4, str. 133-149.

- Vintar, M., Leben, A., Bohanec, M., Dečman, M., Berčič, B. (2003c): Razvoj kataloga življenjskih situacij kot modula inteligentnega portala življenjskih situacij. Zaključno poročilo. Fakulteta za upravo, Ljubljana.

- Vintar, M. (2004): "E-uprava - pogled pod lupino". E-uprava: izbrane razvojne perspektive (Vintar, M. in Grad, J., ur.), Fakulteta za upravo, Ljubljana, str. 3-12.

- $\quad$ SEPLS (2003): Strategija uvajanja elektronskega poslovanja v lokalne skupnosti (e-občina). Ministrstvo za informacijsko družbo. http://www.gov.si/mid.

- $\quad$ OECD (2003): The e-Government Imperative. OECD, Paris. 


\section{SUMMARY}

\section{E-government Development trends in Slovenia}

E-government development aimed at increasing the effectiveness and efficiency of operations and providing the citizens and companies with quality and user-friendly services is in the majority of the developed countries fully underway. Introduction of electronic operations in the area of administration operations (e-government) can be analysed from several aspects which include assuring the technological infrastructure, providing suitable legal bases as well as the offer and demand of e-services. Much has been done in the area of assuring the technological and legal infrastructure during the last five years in Slovenia. Intensive development can be noticed also in the e-services provision, i.e. in the administration's electronic operations with the citizens and companies, which the article presents in more detail using the results from researches conducted by the Institute of Informatisation of Administration at the Faculty of Administration. When analysing the e-government development trends in Slovenia, the results from the following researches were taken into account:

- analysis of the presence of administrative districts (AD), municipalities and ministries on the web and of the contents of their web presentations in 1999, 2000 and 2003;

- measuring of the response of the $A D$, ministries, municipalities and National Assembly deputies to the question of an imaginary resident sent by e-mail between 2000-2003;

- analysis of 20 basic public services (according to the European Commission methodology) in 2002 and 2003;

- analysis of the Slovene state portal e-Government within the framework of a comparative analysis and evaluation of life-event portals in 2002, 2003 and 2004.

The analyses of the results obtained from the researches and the comparison by years show an improvement in the situation and increasing e-government sophistication in Slovenia. Nowadays, it is obligatory to find out that administrative organisations present their operations on the web; however, much will still have to be done about the web presentation contents. In 2003, major work was done in the presentation of the AD (introduction of the AD portal) and the ministries, while the presentation of the municipalities lags behind both in the percentage of the municipalities 
Kunstelj, Leben

Trendi razvoja e-uprave v Sloveniji

presented on the web and in the presented contents. The advantage of the $A D$ portal over the websites of individual administrative districts is in information and services being now gathered in one place in a uniform way, which makes their updating easier and more efficient. The information and services mentioned refer especially to the administrative procedures, the implementation of which is the key task of the AD. The uniform guide on administrative services is well accomplished in terms of its structure and contents, with all application forms being available, too. However, one would miss several transaction services, which will give the information provided a real value.

Surprisingly, very few ministries publish the basic data (mainly due to the official hours), but all of them offer at least one contact e-mail address. None of the ministries has published an alphabetical list of services or procedures, however, almost $80 \%$ have provided a description of at least one procedure, which shows that the web contents are not yet adapted to the user needs, but to the internal needs of the ministries. Almost three-fourths of the ministries publish application forms, with only two of them allowing also their electronic submission.

The analysis of municipalities' websites reveals a much worse situation. Unfortunately, an average municipality presents only a third of the analysed contents on its website, which points to a relatively poor presentation of municipalities on the web. However, it has to be taken into account that the websites of larger municipalities are much more comprehensive and technologically developed than those of smaller municipalities. Although municipalities have numerous contacts with citizens and companies, we are surprised by the fact that the procedures, resulted in services for the customers, are very poorly presented. It is, however, interesting and worth mentioning that one municipality allows monitoring of the procedures via the Internet or SMS messages.

The responsiveness of administrative organisations is getting better every year, but is, in our opinion, still not satisfactory. The question sent by a citizen by e-mail was answered by $69 \%$ of the $A D, 40 \%$ of the municipalities, $60 \%$ of the ministries and $42 \%$ of the National Assembly deputies. The majority responded to the question within the first three days, which was surprisingly quick. Nevertheless, the percentage of the answers received shows that we are still far from $100 \%$ responsiveness, which is usual in the operations carried out in a classic way. This weakness will have to be removed as soon 
as possible since the General Administrative Procedure Act provides that the bodies are obliged to answer resident's applications, even if sent electronically.

Based on the methodology introduced by the European Commission, which monitors the development of public electronic services offer on the Internet within the framework of the eEurope programme, a similar analysis was carried out also in Slovenia. The methodology is based on measuring the sophistication level of 20 public services, which are supposed to present model examples of services in the e-government area. The services are assessed by means of a 4-level model, where the electronic service sophistication level indicates how far is the development of an individual service with regard to full electronic handling. The results of the research in 2003 show an improvement in comparison to 2002, but not a substantial one. Among the most developed services, there are services for obtaining birth and marriage certificates, public library services and job finding services. On average, Slovene services are at the first (information) level of development, while the services in the other EU Member States are at the level of interaction. And exactly contrary to the EU, services for citizens are more developed than services for companies in Slovenia, which is quite unusual regarding the fact that companies have more and more frequent dealings with the administration than the residents. A discrepancy in the services for companies is thus as much as $42 \%$, while the services for citizens in Slovenia only slightly lag behind the EU.

As far as the design and the offer of services related to life events are concerned, the Slovenian state portal 'e-Uprava' has made good progress in the period of two years. In the future, it will be necessary to improve especially various ways of access to life events on the portal and the mechanisms of access to services within life events as well as to provide as high as possible level of technological sophistication of offered e-services.

The article also tries to identify some of the reasons for (in our opinion) unsatisfactory state of the e-government in Slovenia and provide some guidelines for further development in this area. In relation to this, it has to be pointed out that the article in fact analyses the development by the end of 2003 , although some measurements have already been performed this year, while the other will be performed by the end of the year, since we wish to continue monitoring the e-government development in Slovenia. 